\title{
Prognosis of subsequent pregnancies after recurrent spontaneous abortion in first trimester
}

\author{
WILLEM VLAANDEREN， PIETER E TREFFERS
}

\begin{abstract}
The outcome of subsequent pregnancies was studied in 24 women with a history of three or more consecutive spontaneous abortions in the first trimester. Twenty one of the women agreed to forgo active treatment during the study period and three received progestogens or surgical intervention. As the outcome of their first pregnancy after recurrent abortion 18 of the 24 women delivered a liveborn infant after 28 weeks or more. Of all 49 pregnancies in the untreated group during the study, 10 ended in abortion. Only one woman in the study failed to achieve a live birth.

Except in exceptional cases encouraging women with recurrent abortion to keep trying for a successful outcome is just as effective as currently recommended treatments.
\end{abstract}

\section{Introduction}

Spontaneous abortion in the first trimester of pregnancy is usually preceded by embryonic death several weeks before the first clinical signs of expulsion. Loss of a vital, healthy looking embryo is rare, occurring in not more than $5 \%$ of cases in some series. ${ }^{12}$ In most early spontaneous abortions the embryo shows chromosomal aberrations $^{34}$ or structural defects of non-chromosomal origin. Some $10-15 \%$ of all pregnancies end in early spontaneous abortion and many more conceptuses are lost within the first weeks without clinical signs of pregnancy. ${ }^{56}$ Early embryonic death without signs of maternal disease is also common in many animals, ${ }^{78}$ probably also as a consequence of conception errors. ${ }^{9}$

Early spontaneous abortion therefore seems to be a natural process leading to survival of the fittest embryos, so that except in exceptional cases treatment would appear to be useless. Nevertheless, a woman who has had three abortions in succession may be hard to convince and treatment with vitamins, hormones, antibiotics, psychotherapy, and other measures has been tried, ${ }^{10-13}$ apparently with success. Few studies, however, have included a placebo treated control group.

In a double blind trial of progesterone Goldzieher found no significant difference between the treated and control groups, roughly a fifth of pregnancies in each group ending in abortion. ${ }^{14}$ Harrison reported a trial of human chorionic gonadotrophin in pregnancies proved viable by ultrasonography. Ten treated women continued their pregnancies to term; seven of the 10 women given placebo aborted. ${ }^{\text {is }}$ Mowbray and coworkers studied an immunological treatment, in which women received injections of their own or their husbands' lymphocytes. Seventeen out of 22 women given paternal cells had successful pregnancies $(77 \%)$ compared with 10 out of 27 who were injected with their own cells $(37 \%){ }^{16}$

\section{Lukas Ziekenhuis, 7334 DZ, Apeldoorn, The Netherlands}

WILLEM VLAANDEREN, MD, consultant in obstetrics and gynaecology

University of Amsterdam

PIETER E TREFFERS, MD, professor of obstetrics and gynaecology

Correspondence and requests for reprints to: Dr Vlaanderen.
We report the outcome of subsequent pregnancies in women with a history of recurrent abortion who were not given any treatment at all.

\section{Patients and methods}

The study group comprised 27 women who during 1970-85 were referred to our department in Apeldoorn after three or more successive spontaneous abortions. In The Netherlands abortion is defined as loss of pregnancy in the first 16 weeks after the first day of the last menstrual period or in the first 14 weeks after conception. All pregnancies were proved by urine tests or histological examination. Three women, all with secondary habitual abortion (that is, with children from previous pregnancies) stopped their attempts after their third abortion. Of the remaining 24 women, 21 agreed to continue trying for a successful pregnancy without treatment and three sought and received treatment from other gynaecologists. Seventeen of the 24 women were childless, having never achieved a successful pregnancy. Two of the three women who sought treatment elsewhere had had successful pregnancies in the past.

\section{Results}

All 24 women became pregnant after their three abortions, though in one case this next pregnancy was ectopic. With the exclusion of this case the risk of abortion in the untreated group proved to be $20 \%$ (4/20 cases). Of all 49 subsequent pregnancies registered in this group, $10(20 \%)$ ended in abortion (table).

Outcome of subsequent pregnancies in 21 untreated and three treated women with history of three or more consecutive spontaneous abortions

\begin{tabular}{|c|c|c|c|c|}
\hline & \multicolumn{2}{|c|}{$\begin{array}{l}\text { Outcome of first pregnancy after } \\
\text { three consecutive abortions }\end{array}$} & \multicolumn{2}{|c|}{$\begin{array}{c}\text { Outcome of all subsequent } \\
\text { pregnancies }\end{array}$} \\
\hline & $\begin{array}{c}\text { Treated women } \\
\quad(\mathrm{n}=3)\end{array}$ & $\begin{array}{l}\text { Untreated women } \\
\quad(n=21)\end{array}$ & $\begin{array}{l}\text { Treated women } \\
\quad(n=3)\end{array}$ & $\begin{array}{l}\text { Untreated women } \\
\quad(n=21)\end{array}$ \\
\hline $\begin{array}{l}\text { Live birth } \\
\text { Abortion } \\
\text { Ectopic }\end{array}$ & $\begin{array}{l}2 \\
1\end{array}$ & $\begin{array}{r}16 \\
4 \\
1\end{array}$ & $\begin{array}{l}4 \\
1\end{array}$ & $\begin{array}{r}37 \\
10 \\
2\end{array}$ \\
\hline
\end{tabular}

Two of the three treated women received progestogens and delivered a total of four living children (table). The third woman had surgical correction of her bicornuate uterus, had one more abortion, and subsequently was rendered infertile by blocked fallopian tubes. She was the only woman in the group of 24 who did not succeed in having a live birth. Some women succeeded only after a considerable series of consecutive abortions. The overall sequence of events in the 24 women after entry to the study was as follows: live birth, 18 women (two treated); abortion/live birth, one; abortion/abortion/live birth, four; abortion/infertile, one (treated).

Of all abortions in our group (before and after entry into the study), 38 were complete and available for examination; 34 showed early to very early death of the embryo, suggesting-just as in solitary abortions-a mainly ovular origin for the repeated loss of pregnancy.

\section{Discussion}

People seeking help for recurrent abortion deserve sympathy and understanding for their problem. Extensive examination, however, is seldom helpful. Our finding that most abortions in the first trimester were a consequence of early embryonic death seemed 
good reason to accept the repeated loss as probably inevitable and to refrain from any kind of treatment.

The risk of abortion in the untreated group turned out to be roughly $20 \%$ (10/49), somewhat higher than the $10-15 \%$ expected in the population at large but still very moderate. More important, however, the overall chance of these women eventually having a live birth was hardly diminished at all.

The results in our group of untreated women with habitual abortion agree with those in some earlier series ${ }^{141718}$ but contradict those of Harrison ${ }^{15}$ and Mowbray et al. ${ }^{16}$ The high incidence of abortions in the control groups studied by Harrison and Mowbray $e t$ $a l$, however, question the nature of the placebos used.

We believe that encouraging these couples to continue trying to achieve a successful pregnancy is just as effective as any other treatment recommended to date.

\section{References}

Vlaanderen W. De spontane abortus. Amsterdam: University of Amsterdam, 1983. (Thesis.) 2 Robinson HP. The diagnosis of early pregnancy failure by sonar. $\mathrm{Br} f$ Obstet Gynaecol 1975;82:849-57.

3 Boué JG, Boué A, Lazar P, Guguen S. Outcome of pregnancies following a spontaneous abortion with chromosomal anomalies. Am J Obstet Gynecol 1973;116:806-12.
4 Lauritsen JG. Aetiology of spontaneous abortion. Acta Obstet Gynecol Scand 1976;52(suppl): $1-29$

5 Miller JT, Williamson E, Glue J, Gordon YB, Grudzinskas JG, Sykes A. Fetal loss after implantation. Lancet 1980;ii:554-6.

6 Edmonds DK, Lindsay KS, Miller JF, Williamson E, Wood RJ. Early embryonic mortality in women. Fertil Steril 1982;38:447-53.

7 Corner GW. The problem of embryonic pathology in mammals with observations upon intra-uterine mortality in the pig. Am $\mathcal{F}$ Anat 1923;31:523-45.

8 Wilson JG. Environmental effects on intrauterine death in animals. In: Porter IH, Hook GB, eds. Human embryonic and fetal death. New York: Academic Press, 1980:19-27.

9 McFeely RA. Chromosome abnormalities in early embryos of a pig. $\mathcal{F}$ Reprod Fertil 1967;13: 579-81.

10 Javert CT. Spontaneous and habitual abortion. New York: McGraw-Hill, 1957.

11 Gerbard L, vWendt A, vHolst Th, Runnebaum B. Zur Diagnostik und Therapie des habituellen Abortes in der Praxis des Frauenarztes. Geburtshilfe Frauenheilkd 1981;41:797-803.

12 Tupper $\mathrm{C}$, Weil RJ. The problem of spontaneous abortion IX. The treatment of habitual abortion by psychotherapy. Am $\mathcal{Y}$ Obstet Gynecol 1962;83:421-4.

13 Stray-Pedersen B, Stray-Pedersen S. Etiologic factors and subsequent reproductive performance in 195 couples with a prior history of habitual abortion. Am F Obstet Gynecol 1984;148:140-6.

14 Goldzieher JW. Double blind trial of a progestin in habitual abortion. JAMA 1964;188:651-4.

15 Harrison RF. Treatment of habitual abortion with human chorionic gonadotropin: results of open and placebo-controlled studies. Eur J Obstet Gynecol Reprod Biol 1985;20:154-68.

16 Mowbray JF, Liddel H, Underwood JL, Gibbings Ch, Reginald PW, Beard RW. Controlled trial of treatment of recurrent spontaneous abortion by immunisation with paternal cells. Lancet 1985;i:941-3.

17 Speert H. Pregnancy prognosis following repeated abortion. Am f Obstet Gynecol 1954;68:665-73. 18 Goldzieher JW, Benigno BB. The treatment of threatened and recurrent abortion. Am $7 \mathrm{Obstet}$ Gynecol 1958;75:1202-4.

(Accepted 9 April 1987)

\section{SHORT REPORTS}

\section{Endoscopic injection of alcohol for bleeding from gastroduodenal vascular anomalies}

Focal gastroduodenal vascular anomalies may account for almost a quarter of cases of unknown upper gastrointestinal haemorrhage. ' Diffuse antral lesions can also produce chronic anaemia. ${ }^{2}$ Although these lesions are sometimes excised, their association with old age and with disorders of the blood, heart, and liver makes less radical treatment preferable. Both electrocoagulation and laser treatment have been used, but neither is widely available ${ }^{34}$ I report on seven patients with vascular anomalies who were treated by endoscopic injection of absolute alcohol.

\section{Patients, methods, and results}

Details of individual patients are given in the table. The diagnosis of lesions was made initially on endoscopic criteria alone but it was supported in cases 3,6 , and 7 by histological evidence. In only one case was the diagnosis known from a previous endoscopy. Focal lesions were diagnosed after acute upper gastrointestinal haemorrhage and consisted of multiple sites except in case 3. Diffuse lesions were diagnosed during investigation of anaemia. The diffuse anomalies appeared as red "tiger stripes" in the antrum and had previously been mistaken for antral gastritis.

Treatment of the focal lesions was by superficial injection of $0.5-1.0 \mathrm{ml}$ absolute alcohol, with a standard endoscopic needle, as near as possible to the centre of the lesions. Treatment was repeated after one week or sooner if the initial bleeding had been severe. Weekly treatment was given until all visible lesions had been obliterated, except in one patient (case 4), who was positive for the human immunodeficiency virus antibody, which prohibited further endoscopy once bleeding was controlled. Treatment of the diffuse antral anomalies was by multiple submucosal injections of alcohol $(0 \cdot 1-0 \cdot 2 \mathrm{ml})$ at about $5 \mathrm{~mm}$ intervals along the "tiger stripes" to a total of 3-8 $\mathrm{ml}$ alcohol per session. Monthly treatments were given with the aim of reducing blood loss so that transfusions were no longer required to maintain the haemoglobin concentration above $100 \mathrm{~g} / \mathrm{l}$. No attempt was made to eradicate the lesion, which in both cases covered most of the gastric antrum. All patients received an $\mathrm{H}_{2}$ antagonist during treatment.

A mean of 3.8 treatments were given to patients with focal lesions. Bleeding occurred again during treatment from newly observed lesions in three cases, from iatrogenic ulcer in one, and from incompletely treated lesions in two. One deep and one shallow ulcer were produced in the first two patients who were treated, but both healed rapidly. After treatment these patients were followed up for a mean of eight months with no further haemorrhage. The two patients with diffuse lesions showed a decrease in antral vascularity that corresponded to a reduction in transfusion requirements to zero in one patient, and from 3 units a month in the three months before the first treatment to a mean of 1.3 units a month in the subsequent nine months in the other patient.

\section{Comment}

Electrocoagulation for mucosal vascular anomalies has not produced reliable results, ${ }^{3}$ and the expense of neodymium YAG lasers, which are advocated as the best approach, limits their use. ${ }^{4}$ Injection of alcohol seems to be as effective as lasers but is vastly cheaper and technically simpler. Reduction of the vascularity of diffuse lesions by submucosal injection of a sclerosant is a fairly new concept, most reported cases having been treated surgically. ${ }^{2}$ Endoscopic injection of sclerosants to treat a variety of bleeding lesions is well known in Europe and the Far East but has received little attention in the United Kingdom. The Japanese experience of endoscopic injection of alcohol is extensive and shows good control of bleeding and low complication rates. ${ }^{5} \mathrm{My}$ experience of the technique used for vascular anomalies supports these findings.

Details of patients with mucosal vascular anomalies treated by alcohol injection

\begin{tabular}{|c|c|c|c|c|c|c|c|}
\hline Case No & $\begin{array}{c}\text { Age } \\
\text { (years) }\end{array}$ & Sex & Associated conditions & Site & $\begin{array}{l}\text { No of bleeds or } \\
\text { years of anaemia }\end{array}$ & $\begin{array}{c}\text { No of } \\
\text { treatments }\end{array}$ & $\begin{array}{l}\text { Bleeding free } \\
\text { follow up } \\
\text { (months) }\end{array}$ \\
\hline \multirow{7}{*}{$\begin{array}{l}1 \\
2 \\
3 \\
4 \\
5\end{array}$} & & & Focal lesions & & & & \\
\hline & 85 & M & & Stomach & 6 Bleeds & 9 & 8 \\
\hline & 80 & $M$ & Mitral valve disease & Stomach & & 2 & 11 \\
\hline & 62 & $\mathbf{M}$ & Aortic valve disease & Stomach & 5 Bleeds & 2 & 9 \\
\hline & 34 & $\mathbf{M}$ & Homozygous von Willebrand's (factor VIII $0 \%$ ) & Stomach, duodenum & 3 Bleeds ${ }^{\star}$ & 4 & 7 \\
\hline & 54 & $M$ & Myelofibrosis & Stomach, duodenum & 10 Bleeds $\dagger$ & 2 & 4 \\
\hline & & & Diffuse lesions & & & & \\
\hline 6 & 86 & $\mathbf{F}$ & Aortic valve disease & Antrum & & 3 & 8 \\
\hline 7 & 72 & $\mathbf{F}$ & Mitral valve disease and factor XII deficiency & Antrum & 13 Years & 5 & $\ddagger$ \\
\hline
\end{tabular}

